\title{
Mesenchymal Stem Cells: Pivotal Players in Hematopoietic Stem Cell Microenvironment
}

\author{
Sanaa EL Marsafy ${ }^{1 *}$, Jérôme Larghero ${ }^{2-4}$, Annelise Bennaceur-Griscelli ${ }^{1,5,6}$ and Ali Turhan ${ }^{1,5,6}$ \\ ${ }^{1}$ Assistance Publique-Hôpitaux de Paris. Hôpital Paul Brousse, Laboratoire d' Hematologie Biologique. Villejuif, France \\ ${ }^{2}$ Assistance Publique - Hôpitaux de Paris, Hôpital Saint-Louis, Cell therapy Unit and Clinical Investigation Center (CIC) 1427, Paris, France \\ ${ }^{3}$ University Paris Diderot, Sorbonne Paris Cité, F-75475 Paris, France \\ ${ }^{4}$ INSERM UMR1160, Institute Universitaire d'Hématologie. Hôpital Saint-Louis, Paris France \\ 5INSERM UMR 935, "ESteam Paris Sud ", Stem cell core facility, Institute André Lwoff, University Paris Sud, Paul Brousse Hospital, Villejuif, France \\ ${ }^{6}$ University Paris Sud11, Faculty of Medicine, Kremlin-Bicêtre, France
}

\begin{abstract}
The hematopoietic stem cells (HSC) reside in a specialized microenvironment in the bone marrow (BM) referred to as the osteoblastic and perivascular niches where various components involving the mesenchymal stem cells (MSC) and their progeny are implicated in shaping the HSC compartment. Of interest, the development of various disorders including leukemia, cancers and autoimmune diseases are associated with abrasions and altered functions of MSC. Herein, we focus attention on the subtypes of MSC in the HSC niche with emphasis on their role in controlling normal and malignant hematopoiesis. Additionally, MSC therapeutic potential in targeting tumor cells will be discussed. Delineation of the cross-talk between MSC and HSC is valuable for a better comprehension of the underlying physiopathology of a given hematologic disorder and might pave the way for new therapeutic approaches.
\end{abstract}

Keywords: Mesenchymal stem cells; Hematopoietic niche; Chronic myeloid leukemia; Cell therapy

\section{Introduction}

The hematopoietic stem cells (HSC) reside in privileged sites in the bone marrow (BM) which are termed the HSC niches (endosteal and vascular niches). In these locations, a wide variety of cells including the bone lining osteoblasts, vascular endothelial cells, osteoprogenitors, MSC/stromal cells, osteoclasts, adipocytes, macrophages, immune and neural cells has been proposed to play a crucial hematopoietic regulatory role $[1,2]$. In respect of $\mathrm{MSC}$, the $\mathrm{BM}$, adipose tissue, muscles, synovium, placenta and umbilical cord are enriched in these cells [3]. Of note, characterization of cultured MSC relies on the expression of CD73, CD90, STRO-1 and CD105 and lack of HLA-DR, endothelial (CD31) and hematopoietic (CD34 and CD45) markers (4). Further identification standards of MSC are based on their adherence to plastic surfaces, self-renewal and differentiation potential into osteoblasts, adipocytes and chondrocytes. Nevertheless, their capacity to differentiate into neurons, skeletal muscle and myocardium was also discussed [4-7].

The prospective MSC isolation from different tissues depends on the expression of more specific molecules such as CD271, CD146, mesenchymal stem cell antigen-1 (MSCA-1), Oct4, Nanog, surface specific embryonic antigen-4 (SSEA-4) and Ganglioside2 (GD2) [8,9] (Table 1).

Under normal physiological conditions, MSC are not circulating, however, activation by tissue damage results in their proliferation, differentiation and migration [10]. In this respect, several factors are implicated in the mobilization and homing of MSC such as insulin growth factor-1(IGF-1), the high mobility group box-1 (HMGB1), the basic fibroblast growth factor (b-FGF) and CXCL-5 [10-12]. A combination of erythropoietin (EPO) and granulocyte-colony stimulating factor (G-CSF) was reported to promote MSC migration through enhanced ERK1/2 signaling and expression of matrix metalloprotein-2 (MMP-2) [13].

Of interest, MSC stemness and survival are promoted by hypoxia through mechanisms involving autophagy and up-regulation of self- renewal markers such as oct-4, sox-2 and Nanog [14,15]. However, MSC fate is regulated by several signaling cascades involving the canonical Wnt and TGF- $\beta$ superfamilly. Given the diversity of Wnt proteins and receptors expressed on MSC, Wnt3a interaction with MSC was reported to promote proliferation of undifferentiated MSC rather than MSC differentiation into osteoblasts. On the other hand, interaction of TGF- $\beta 3$ with its specific receptor on MSC was reported to trigger intracellular signaling molecules including SMAD proteins that promote chondrogenic differentiation [16-18]. Other growth factors including the BMP family, IGF, PDGF and FGF act in concert with Wnt and TGF- $\beta$ signaling pathways to direct MSC differentiation $[16,19]$. For instance, activation of BMP2 and IGF2 were reported to promote the osteogenic differentiation of CD271+MSC [20]. Other monitors of MSC differentiation are the micro-RNA (mi-RNAs). This latter are 1922 nucleotide fragment of non-coding RNA that affect various cellular process through post-transcriptional regulation of target genes [21]. A

\begin{tabular}{|l|l|}
\hline $\begin{array}{l}\text { Surface markers } \\
\begin{array}{l}\text { Differentiation } \\
\text { potential }\end{array}\end{array}$ & $\begin{array}{l}\text { Positive: } \\
\text { STRO-1, CD73, CD90, CD105, CD146, } \\
\text { CD271, MSCA-1 }\end{array}$ \\
\hline Properties & $\begin{array}{l}\text { Colony fonic, CD45, CD31, HLA-DR } \\
\text { Adherence } \\
\text { High proliferative potential }\end{array}$ \\
\hline
\end{tabular}

Table 1: In vitro characteristics of MSC.

*Corresponding author: Sanaa EL Marsafy, MD, PhD, Assistance Publique Hôpitaux de Paris. Hôpital Paul Brousse. Laboratoire d'Hematologie Biologique. Villejuif, France, Tel: +33 14249 96; E-mail: elmarsafy.sanaa7@yahoo.fr

Received July 04, 2014; Accepted August 05, 2014; Published August 07, 2014

Citation: EL Marsafy S, Larghero J, Bennaceur-Griscelli A, Turhan A (2014) Mesenchymal Stem Cells: Pivotal Players in Hematopoietic Stem Cell Microenvironment. J Stem Cell Res Ther 4: 225. doi:10.4172/2157-7633.1000225

Copyright: (c) 2014 El Marsafy S, et al. This is an open-access article distributed under the terms of the Creative Commons Attribution License, which permits unrestricted use, distribution, and reproduction in any medium, provided the original author and source are credited. 
large array of mi-RNA has been reported to accelerate or inhibit MSC commitment and lineage differentiation. In this context, expressed miRNA-335 and its encoding gene MEST (mesoderm-specific transcripit homology) in the pluripotent MSC can be modulated by interferon- $\gamma$ (IFN- $\gamma$ ) leading to MSC differentiation [21]. Indeed, the differentiation of MSC is dependent on the mechanisms that control the specific cell lineage and those suppressing the development of other lineage. For instance, the expression of mi-RNA-140 was reported as a specific regulator of chondrogenic differentiation acting, in part, through repression of both CXCL-12 and metalloproteinase with thrombosponin motifs (ADAMTS)-5 [22]. MSC commitment and differentiation towards adipocytes is under the control of signaling cascade emitted by many agents including BMP, Wnt, TGF- $\beta$, insulin and several transcription factors such as CCAAT/enhancer binding protein (CEBPs) and peroxidase proliferator activated receptor (PPAR- $\gamma$ ). Several mi-RNA have been reported to interact with different signaling pathways leading to either enhancement or repression of adipogenesis [23]. In this regard, mi-RNA 27a has been reported to suppress adipocyte differentiation through PPAR- $\gamma$ down regulation [24]. On the other hand, mi-RNA 17-29 cluster have been reported to accelerate adipocyte differentiation by negative regulation of tumorsuppressor Rb2/p130 [25]. Similarly, several types of mi-RNA can modulate signaling pathways and transcriptional factors responsible for osteoblastic differentiation. For instance, mi-RNA 206 was reported to inhibit osteoblastic differentiation through targeting connexin 43 [26]. However, mi-RNA 133 and mi-RNA 135 inhibit oeteogenesis by targeting Runex2 and SMAD 1/5 [27]. On the other hand, mi-RNA 2861 supports BMP2 signaling pathway, hence, promoting osteoblastic differentiation [28]. Given the importance of mi-RNA in managing MSC differentiation, we hypothesize that future modulation of their expression might be a tool for the induction of a particular lineage of MSC differentiation useful for in tissue engineered therapy.

\section{Origin and Localization of MSC within the BM}

Recent studies consistently reveal that MSC are generated in two waves: the first one neuroepithelial-derived and the second one is of non-neural origin [29]. The earliest MSC wave is emerged from the neural crest stem cells (NCSCs), which then migrate from the dorsal neural tube to the aorta-gonads- mesonephros (AGM) region before they join the BM [30,31]. However, the adult perivascular tissue was proposed as the non-neural origin of MSC. This suggestion is relied on the following observations: (A) - the expression of certain markers like CD146, NG2 and platelet derived growth factor receptor $-\beta$ (PDGF-R $\beta$ ) by both the pericytes and MSC (B) - the potential of both MSC and pericytes to differentiate into osteoblasts, chondrocytes and adipocytes, (C) - localization of MSC expressing the pericyte marker, 3G5, in the perivascular niche $[3,32,33]$. The odontoblasts and the inter-vertebral disc were additionally reported as non-neural sources of MSC $[3,34]$. Of interest, epithelial to mesenchymal transition (EMT) was proposed as a potential origin of MSC. In such process, the epithelial cells lose polarization and basal junction with subsequent cytoskeleton reorganization and lastly acquire a mesenchymal like identity such as the multipotent differentiation potential [35].

Localization of MSC in the HSC niches revealed the presence of CD271+ MSC subtype in close vicinity to the bone lining cells and in the BM parenchyma. These CD271+MSC were reported to express Oct4 and SSEA-4 multipotent markers and possess the potential to differentiate into osteogenic, adipogenic, pericytic lineages $[8,16,36]$. However, MSC CD146+, were detected in association with the BM sinusoids and do express VCAM-1, CD44 and PDGFR- $\alpha$ and $\beta$ while lacking the expression of pan endothelial marker (CD31/PECAM-1) and the smooth muscle $\alpha$-actin [37,38]. A subpopulation of MSC CD146+ cells with long dendrites do express high levels of CXCL-12 and are termed CXCL12-abundant reticular (CAR) cells [39,40]. This latter, are capable to differentiate into adipo-osteogenic progenitors and can support homing and maintenance of the HSC. In addition, CAR cells have demonstrated a role in the development of B lymphocytes, plasmacytoid denderitic and NK- cells [41,42]. Worthy mentioning, the co-expression of CD146 and CD271+ on MSC is dependant on aging and the localization of these cells within the BM niche. In this respect, MSC CD271+ CD146+ was reported as the prevalent phenotype in the fetal BM being substituted by CD271+CD146- cells in the adulthood [43]. The oxygen gradient within the $\mathrm{BM}$ niche might underlie the prevalence of MSC CD146+ in the perivascular niche and MSC CD271+ in the hypoxic endostium [8,44].

In addition, the perivascular niche harbors a MSC subtype expressing the intermediate filament protein, Nestin. This subpopulation is a selfrenewing with a tri-lineage differentiation potential and do express high levels of HSC maintenance genes including SCF and Angiopoietin-1 (Ang-1) [45]. Furthermore, MSC Nastin+ are in spatial association with both HSC and adrenergic nerve fibers where HSC retention is regulated by opposing signals derived from the sympathetic nerve fibers and the adjacent macrophages [46]. Of interest, implication of the immune $\mathrm{T}$ cells in the induction of the osteoblastic lineage was recently reported following intermittent treatment of MSC Nestin+ by parathyroid hormone (PTH) [47]. In this context, the interaction of the PTH with its specific receptor (PTH- related protein receptor, PPR), expressed on the T lymphocytes will trigger the production of $\mathrm{Wnt} 10 \mathrm{~b}$ that triggers the Wnt signaling pathway in MSC with subsequent osteogenic differentiation $[47,48]$.

Furthermore, MSC expressing leptin receptors (lepr+ MSC) were identified mainly in the perivascular niche. Leptin is a cytokine expressed in the white adipose tissue and acts centrally by stimulating the hypothalamus with subsequent expression of several neuropeptides that contribute to bone loss. Alternatively, through a peripheral mechanism, leptin binds to the specific receptors expressed on the MSC resulting in enhanced osteogenic differentiation. Of note, lepr+ MSC do not express nestin, however, they do express high levels of CXCL-12 suggesting an overlap with CAR cells [49,50]. Of note, a balanced differentiation of MSC into osteoblasts and adipocytes is required for optimal niche function. However, aging favors the formation of adipocytes that negatively regulate the hematopoiesis, partially, through the secretion of adiponectin [51]. Taken together, these studies provide evidence that MSC subpopulations are important players in the BM HSC niches.

\section{MSC Orchestrate HSC Fate in the BM Niche}

The osteoblastic and the perivascular niches have been described as privileged zones for regulation of HSC fate. The osteoblastic niche is preferentially located in the epiphysis of long bones, precisely, in the trabecular's endosteum and to a lesser extent in the cortical bone of the diaphysis (bone shaft). However, the perivascular niche encircles the $\mathrm{BM}$ vasculature [52,53].

In the mouse, using SLAM family receptors, HSC were detected adjacent to the vascular endothelium all through the BM and nearby the trabecular endostieum. Nevertheless, multipotent and restricted progenitors were distributed although the long bone diaphysis [53-55]. Otherwise, multimodal imaging protocols have proved the presence of two putative HSC niches, namely, the reconstitution and the homeostatic 
niches [56]. The former includes the BM zones displaying the highest bone remodeling activity and enhanced blood supply thus allowing for HSC cycling and augmentation of the hematopoietic stem and progenitor cell pool. Alternatively, the latter niche is evenly distributed all through the BM and harbors the steady-state HSC (in the G0/G1 phase of the cell cycle) [57]. Indeed, localization of hematopoietic stem and progenitor cells in a given zone is likely dependent on its cellular and cytokine profile. For instance, cells of the perivascular niche including CAR, Nestin+ MSC, Lpr+ MSC and endothelial cells were reported as the main physiological source of CXCL-12 and SCF. Of interest, conditional deletion of these cytokines from the perivascular stromal cells and endothelial cells resulted in selective depletion of HSC while lymphopoiesis was spared, most likely due to localization of lymphopoiesis in the endosteal niche [50-57]. In this latter location, the osteoblasts and the neighboring MSC were proved to produce a number of factors including CXCL-12, IL-7 and SCF which are known to maintain the common lymphoid cells and B-lymphoid progenitors. Accordingly, deletion of SCF from the osteoblasts, CAR and Nestin+ MSC was reported to deplete the B-lymphoid progenitors with no deleterious effect on the HSC frequency or function [50]. Likewise, conditional deletion of CXCL-12 from the osteoblasts resulted in depletion of the lymphoid lineage rather than the HSC $[58,59]$.

There is ever-increasing evidence for the necessity of a specialized BM microenvironment to promote HSC division indispensable for self-renewal and production of various differentiating descendants. For instance, after transplantation, HSC divide rapidly and symmetrically to replenish the stem cell pool. Some of these cells polarize and divide asymmetrically to give one identical stem cell and another cell designated to differentiate after several rapid symmetric divisions. The initial symmetric HSC division is independent of regulatory cytokines. Yet, contact with the supporting microenvironment seemed critical for symmetric and asymmetric division of both primitive and committed progenitors. Such contact with stromal cells promotes the expression of a battery of HSC genes that regulates adhesion, cytoskeleton rearrangement and DNA repair [60,61]. The spatial distribution of the adhesion molecules plays a key role in defining the cell shape and the asymmetric cell division through biases of polarized actin and microtubules networks as well as biases of segregated DNA which dictates distinct fates for generated daughter cells $[62,63]$. Of interest, myosin-IIB (MYIIB) represents the major non muscle myosin II isoform in hematopoietic stem and progenitor cells. The contractile forces of polarized myosin-IIB (MYIIB) could influence the differential segregation of HSC fate determinants and tapering of MYIIB isoform was observed along with the HSC differentiation being replaced by the activated MYIIA isoform [64].

Of note, HSC fate in terms of self-renewal and differentiation into terminally mature progenies is under the control of key regulators involving Wnt and Notch that work in concert with other signaling pathways for establishing a balance between these two opposing cell outcomes [65]. For instance, Wnt ligands, expressed by BM MSC and primitive HSC, were reported to function via paracrine and autocrine mechanisms leading to canonical or non- canonical signaling pathway activation. In the former one, the downstream signaling is established by binding of Wnt ligand with Frizzled receptor/Lrp co-receptor, followed by stabilization and nuclear transfer of $\beta$-catenin which binds to $\mathrm{T}$-cell factor complex leading to the expression of several target genes $[66,67]$. Nevertheless, the impact of Wnt on the HSC and committed progenitors was debatable. In one study, enhanced autonomus canonical Wnt signaling in HSC by retroviral over-expression of $\beta$-catenin was reported to expand the HSC while inhibiting their differentiation both in vitro and in vivo [68]. In other studies, deletion of $\beta$ and $\gamma$-catenin revealed no effect on HSC frequency and differentiation potential. The existence of other functionally active pathway has been proposed as a possible compensatory mechanism to overcome the double absence of $\beta$ and $\gamma$-catenin $[69,70]$. Worthy mentioning, MSC- paracrine Wnt secretion was reported to induce HSC quiescence, in part, through up-regulation of the cyclin dependent kinase inhibitor, p21 [71,72]. However, autonomus Wnt signaling in MSC was reported to repress HSC retention factors including angiopoietin-1, SCF and VCAM-1 leading to HSC activation [73].

In non-canonical Wnt signaling, activation of Wnt/JNK/PCP or Wnt-Ca ${ }^{+2}$ pathways is dependent on the employed member of Wnt's family and the type of the engaged receptor $[65,74]$. Again, the influence of the non-canonical Wnt signaling on HSC is controversial. For instance, Wnt5a injected into mice engrafted with human repopulating cells have enhanced the HSC multilineage reconstitution potential [75]. However, others have demonstrated that Wnt5a maintains HSC in a G0 state. A possible antagonistic response between Wnt5a and Wnt3a on HSC was proposed as a possible mechanism for the observed HSC quiescence [74,76]. Indeed, quiescence of HSC pool is under the control of other soluble Wnt antagoniste including Wnt inhibitory factor-1 (WIF-1) secreted frizzled-related proteins (SFRPs), sclerostin (SOST) and Dickkopf (DKK). These Wnt antagonists are secreted by MSC, BM stromal cells, osteoblasts and osteoclasts [65].

In addition to Wnt signaling, Notch activities have been implicated in controlling HSC biology. Notch signalling is triggered by the interaction of Notch ligand with the appropriate receptor leading to nuclear translocation of the receptor's intracellular domain and ultimate transcriptional regulation of multiple genes including Hes or Hes related (Hrt) family genes. These genes encode for basic HLH proteins that, in general, function as DNA-binding transcriptional repressors [77].

The dual capacity of the BM stromal cells, in terms of eliciting and responding to Notch signalling, was attributed to simultaneous expression of Notch-receptors and Jagged-1 [78]. Of interest, treatment of mice with intermittent parathyroid hormone (PTH) revealed enhanced Jagged-1 expression in osteoblasts with subsequent Notch signaling in HSC leading to their expansion [79].

Furthermore, mouse primitive HSC transduced with retrovirus encoding for Notch-1 revealed enhanced potential to self-renewal and differentiation to myeloid and lymphoid lineages both in vivo and in vitro [80]. Moreover, human-mouse xenotransplantation models proved evidence that Jagged-1 can maintain and expand primitive human hematopoietic cells capable of multi-lineage reconstitution in vivo without loss of progenitors [78,81].

Worthy mentioning, HSC fate regulation engage other molecules including osteopontin and thrombopoietin-1 which are involved in anchoring the HSC to the niche and ensure their maintenance in G0 stage of the cell cycle $[9,82]$. The perivascular Schwann cells, marked by glial fibrillary acidic protein (GFAP), also play a role in the induction of HSC quiescence through the activation of latent TGF- $\beta$ [83]. In addition, local calcium gradient and hypoxia in the endosteal share in maintenance of the HSC quiescence [41]. Hypoxia was reported to induce the expression of cyclin dependent kinase inhibitor genes and the accumulation of the hypoxia inducing factor-1 (HIF-1) with subsequent up-regulation of HSC maintenance genes [84]. Of interest, acute lymphoid leukemia (ALL), even under normal oxygen tension, showed selective activation of HIF-1a with subsequent activation of 
Notch signaling leading to expansion of leukemic pool $[85,86]$. Similar augmentation of HIF- 1 a was reported in CML stem cells, explaining in part, their survival and resistance to conventional chemotherapy [87]. Taken together, the interference with HIF signaling pathway might be a successful approach to execute malignant cells.

MSC play a crucial role in HSC traffic, in part, through CXCR4/ SDF-1, SCF/c-Kit and Slit-2/Robo-4 axis [88,89]. In addition, perivascular Nestin+ MSC, in response to sympathetic nerve signaling, were reported to slow down the expression of HSC retention factors including the CXCL-12, Ang-1, SCF and VCAM-1 leading to egression of HSC out of the BM. Nevertheless, neighboring CD169+macrophages have indirect HSC holding action which can be inhibited by G-CSF leading to release of HSC in the peripheral circulation [90,91]. As a final point, MSC could influence the HSC fate through modulation of the immune response. One scenario implicates the secretion IFN- $\gamma$ by activated NK cells which, in turn, augment HLA-G expression on MSC. Binding of HLA-G to the inhibitory receptor ILT2 expressed on NK cells will lead to suppression of NK downstream signaling pathway [92]. Other mechanisms relay, in part, on the inflammatory cytokine that up-regulate a variety of MSC adhesion molecules including ICAM-1 and VCAM-1 [93]. Furthermore, suppression of $\mathrm{BM}$ microenvironment might be the consequence of MSC production of inhibitory cytokines, nitric oxide, cyclooxygenase and indolamine 2,3 dioxygenase (IDO) $[94,95]$.

\section{MSC-leukemic Stem Cell Crosstalk}

Experimental transplantation models of human LSC into immunodeficient mice have proved that leukemic stem cells (LSC), like their normal HSC counterparts, reside in specific niches in the BM microenvironment. In this location, LSC engraft the endosteal niche and expand to the neighboring perivascular endothelium prior to evasion of the peripheral circulation [96]. Modulation of the BM microenvironment might be a prerequisite for changing the outcome LSC. In this regard, mice treated with PTH were shown to express high levels of TGF- $\beta 1$ owing to osteoblastic cell activation and bone remodelling. In this model, transplantation of myeloid LSC showed maintenance inhibition of chronic myeloid leukaemia (CML) and attenuation of CML disease manifestations. Alternatively, under the same experimental conditions, acute myeloid leukaemia (AML) was insensitive to increased TGF- $\beta 1$ and revealed accelerated engraftment likely due to deficient expression of TGF- $\beta 1$ receptors in this type of leukaemia. Taken together, these studies prove a differential sensitivity of CML and AML to TGF- $\beta 1$-modified BM microenvironment and propose the use of PTH treatment for boosting the CML-specific therapy [97].

Further modification of the BM microenvironment was achieved by an experimental deletion of Dicer 1 gene in early osteoprogenitors [98]. Such intervention provoked the development of myelodysplasia and AML in the manipulated mice and indicated that genetic anomalies in the endosteal niche could be a predisposing factor for the development of LSC [98].

Of interest, in myelodysplastic syndrome (MDS), MSC have demonstrated critical aberrations including, among others, epigenetic changes, reduced proliferation and impaired osteogenic differentiation as well as premature senescence. Furthermore, the expression of key molecules engaged in the interaction with HSC such as osteopontin, jagged-1, SCF and Ang-1 was reduced [99]. Alternatively, normal in vitro MSC support of hematopoiesis was reported by other investigators, in spite of the presence of severe chromosomal aberrations in MDS-
MSC [100]. Indeed, there is mounting evidence for a multitude ways in which the MSC can support a variety of malignant hematopoietic disorders. For instance, MSC can enforce LSC survival and adhesion, in part, through the secretion of various inflammatory mediators including CCL2, and IL- 8 as well as the expression of CD44 adhesion molecule $[101,102]$. The importance of CXCL-12/CXCR-4 axis in CML homing and mobilization was proved during imatinib treatment which enhanced CXC-R4 expression on the leukemic cells, thus, facilitating their mobilization of to the BM [103]. However, selective blockage of CXCL-12/CXCR-4 axis by AMD3100 or AMD11070 molecules, in association with the appropriate chemotherapy, was used as a tool for eradicating residual leukemia cells $[104,105]$.

Additionally, BM stromal cells were reported to express high levels of placental growth factor (PGF) which is implicated in enhanced angiogenesis and CML growth. In a mouse model of human CML, a therapeutic protocol combining PGF inhibitor and imatinib was reported to enhance survival of affected mice [106].

Additionally, MSC expression of asparagine synthetase and secretion of asparagine was reported to defend ALL cells from asparaginase cytotoxic effect [107].

In multiple myeloma (MM), protection of the malignant cells from the apoptotic action of bortezomib was achieved by the agonistic action of IL-6, secreted by MSC, and the vascular endothelial growth factor (VEGF) $[108,109]$.

Yet, MSC from MM patients revealed impaired osteogenic potential which could explain, in part, the defective bone formation in later stages of the disease [110]. Worthy mentioning, BM infiltration with malignant lymphoma cells was reported to be associated with ectopic lymph node follicular-like reticular cells (FRC). These latter, represent BM MSC that acquire a complete FRC phenotype under the influence of lymphocyte- secreted cytokines including the TNF- $\alpha$ and lymphotoxin $\alpha 1 \beta 2$. These ectopic lymph nodes will recruit more lymphoma cells and promote their survival and multiplication [111].

The $\mathrm{BM}$ is a referred site for breast and prostate cancer metastasis where MSC and their progeny are integrated in the cancer niche. In this location, stromal fibroblasts represent a mixture of normal and cancer associated fibroblasts (CAF). These latter might represent a state of epithelial to mesenchymal transformation of the tumor parenchyma or might be a consequence of chronic inflammation and tumor epithelial dysplasia. The secretion of TGF- $\beta$ was reported to accelerate the differentiation of MSC into CAF that are recruited to the tumor area in SDF-1 $\alpha$ dependent manner [112].SDF-1 can trigger CAF cells via JAK2/STAT3 and MAPK/ERK signaling pathways with subsequent organization of actin filaments and cytoskeleton [113,114]. Furthermore, SDF-1 was reported to recruit endothelial progenitor cells (EPCs) into carcinomas, thus, promoting the angiogenesis and the tumor growth [115]. Other mechanisms implicating MSC in the tumor growth include inhibition of dendritic cell co-stimulatory markers and IL-10 secretion, secretion of pro-angiogenic growth factors and the potential to differentiate into fibroblasts, pericytes and endotheliallike cells [116,117]. Besides, MSC might provide tumor protection likely through the production of several anti-apoptotic factors such as hepatocyte growth factor (HGF), insulin-like growth factor (IGF-1), basic fibroblast growth factor (b-FGF) and granulocyte/macrophage colony stimulating factor (GM-CSF) [118].

Alternatively, MSC could inhibit tumor growth by several mechanisms including the secretion of pro-inflammatory cytokines that enhance infiltration of macrophages and monocytes to the tumor area 
[119]. DKK-1 secretion by MSC and inhibition of $\beta$-catenin signaling were reported to inhibit the breast cancer $[120,121]$. Similarly, the secretion of TGF- $\beta 3$ and HGF has been demonstrated to interfere with the proliferation of hepatic cell carcinoma via up-regulation of p21, p27 and subsequent inhibition of ERK1/2 signaling pathway [122].

Whether MSC and a given type of leukemic cells would share the same genetic abrasion was the field of debatable data. For instance, the detection of mixed-lineage leukemia (MLL-4) fusion gene, characteristic of infant acute lymphoblastic leukemia (pro B-ALL) in both LSC and MSC, has suggested a common emerging cellular origin $[123,124]$. However, other studies have demonstrated that MSC are spared of the chromosomal anomalies characterizing the malignant clone in $\mathrm{CML}, \mathrm{Ph}+$, bi-phenotypic leukemia or myelodysplastic syndrome JAK2 V617F [125-127].

\section{MSC-based Therapy-in the Context of Malignant Disorders}

MSC are used experimentally in a variety of clinical contexts seeking for tissue repair, eradication of malignant cells as well as the treatment of graft-versus-host disease and autoimmune diseases. Such opportunity is attributed to MSC immune modulation capability, lack of immunogenicity and secretion of a wide range of mediators involving interleukines, chemokines as well as anti-inflammatory and angiogenetic factors. Additionally, MSC behavior of tumor tropism and their potential for drug and gene delivery were believed crucial for targeting cancer cells [128]. To achieve this therapeutic goal, attention must be paid to ex-vivo expansion protocols. For instance, the addition of exogenous growth factors such as FGF- $\beta$ to the culture media has been reported to optimize the proliferation of CB-derived MS [129]. Furthermore, culture of dermis isolated stem cells under hypoxic condition has been reported to enhance ex vivo chondrogenesis, hence, the MSC potential for cartilage engineering [130]. The presence or absence of xeno serum in the culture media is another contributing factor for MSC expansion [131]. Culture media supplemented with autologous activated platelet-rich plasma, in replacement of fetal bovine serum, was proved safe and efficient in expanding the limited harvest of umbilical cord blood (UCB)-MSC with conservation of their multi-differentiation potential [132]. Likewise, replacement of the animal serum with human platelet lysate was reported to promote growth and expansion of BM-MSC in clinical scale cultures [133].

Taking into consideration the risk of transformation during the process of culture, regular karyotype and telomerase examination are highly recommended to ensure absence of mutations and genetic aberrations in expanded MSC [134]. Selection of MSC donor age, the use of adequate MSC numbers, the choice of the route and timing of MSC administration are also required for attaining good results [135]. Of interest, MSC transplantation trials in adult individuals have reported no significant safety signals except the development of transient fever. Yet, several adverse events such as acute infusion toxicity, infections and different organ dysfunction have been recorded in a low scale and require further investigations [136].

In view of their immunosuppressive potential and the regenerative capacity, MSC were used to prevent graft versus host disease (GvHD) in allogenic transplantation settings. There is ever-increasing evidence for enhanced proliferation and engraftment of HSC following cotransplantation of MSC and CD34+. This effect could be explained by boosting $\mathrm{T}$ cell recovery and interference with graft-versus-host disease development [137]. The MSC production of cytokines involving IL2, G-CSF and GM-CSF could underlie, in part, the observed HSC proliferation. MSC secretion of anti-inflammatory cytokines including IL-4 and IL-10 were believed to support the development of CD4+Tregulatory cell (Treg), thus controlling the development of GvHD $[138,139]$. Of interest, optimization of the MSC immunomodulatory effect could be attained by priming with certain inflammatory mediators such as IFN- $\gamma$, IL- $1 \mathrm{~b}$ and TNF- $\alpha$ [134]. Additionally, pretreatment of MSC with $\beta$-catenin was reported to enhance HSC self-renewal in an experimental transplantation model. Hence, Wnt-treated MSC was suggested to be an attractive tool in HSC transplantation settings [140].

The use of MSC for targeting malignant cells relies on several mechanisms including tumor tropism and the capacity to deliver therapeutic genes to the tumour niche. Indeed, certain factors including the monocyte chemotactic protein-1 (MCP-1), IL-8, TGF- $\beta$ and VEGF were reported as a requirement for MSC migration and tumor invasion [141,142]. In addition, there is a mounting evidence for successful use of engineered MSC expressing certain genes for targeting malignant cells. In this regard, MSC engineered for herpes simplex virus thymidine kinase gene expression were used in the presence of ganciclovir for targeting glioma cells [143]. Additionally, intra-tracheal injection of MSC expressing CX3CL-1, an immuno-stimulatory chemokine, was reported to inhibit certain experimental lung tumors [144]. The antitumor activity of recombinant human TRAIL (TNFrelated apoptosis inducing ligand) was previously reported. However, its use in vivo was limited by its rapid clearance and short plasma halflife. Interestingly, MSC- TRAIL transduced were used as a constant source of this factor and appeared promising for targeting cancer cells $[145,146]$.

\section{Conclusion}

MSC offer the majority of stromal cell lineage including chondrocytes, osteoblasts and adipocytes. Additionally, they co-localise with HSC and LSC in the BM niche and influence their fate decision through mutual cross talk. The impact of MSC on the tumorogenesis could be attributed, in part, to their immune modulation behaviour and tendency for tumor tropism. This latter ability was exploited for deliverance of therapeutic genes to the tumour niche for targeting malignant cells. Clearly, MSC should be viewed as a double-edged weapon, hence, further researches are recommended to understand the complex interactions between tumor cells and the surrounding microenvironment.

\section{References}

1. Nwajei F, Konopleva M (2013) The bone marrow microenvironment as niche retreats for hematopoietic and leukemic stem cells. Adv Hematol 2013: 953982. [PubMed]

2. Warr MR, Pietras EM, Passegué E (2011) Mechanisms controlling hematopoietic stem cell functions during normal hematopoiesis and hematological malignancies. Wiley Interdiscip Rev Syst Biol Med 3: 681-701. [PubMed]

3. Huang S, Leung V, Peng S, Li L, Lu FJ, et al. (2011) Developmental definition of MSCs: new insights into pending questions. Cell Reprogram. 13: 465-472. [PubMed]

4. Dominici M, Le Blanc K, Mueller I, Slaper-Cortenbach I, Marini F, et al. (2006) Minimal criteria for defining multipotent mesenchymal stromal cells. The International Society for Cellular Therapy position statement. Cytotherapy 8: 315-317. [PubMed]

5. Kondo T, Johnson SA, Yoder MC, Romand R, Hashino E (2005) Sonic hedgehog and retinoic acid synergistically promote sensory fate specification from bone marrow-derived pluripotent stem cells. Proc Natl Acad Sci USA 102: 4789-4794. [PubMed]

6. Dezawa M, Ishikawa H, Hoshino M, Itokazu Y, Nabeshima Y (2005) Potential of bone marrow stromal cells in applications for neuro-degenerative, neuro- 
Citation: EL Marsafy S, Larghero J, Bennaceur-Griscelli A, Turhan A (2014) Mesenchymal Stem Cells: Pivotal Players in Hematopoietic Stem Cell Microenvironment. J Stem Cell Res Ther 4: 225. doi:10.4172/2157-7633.1000225

Page 6 of 9

traumatic and muscle degenerative diseases. Curr Neuropharmacol 3: 257 266. [PubMed]

7. Miyahara Y, Nagaya N, Kataoka M, Yanagawa B, Tanaka K, et al. (2006) Monolayered mesenchymal stem cells repair scarred myocardium after myocardial infarction. Nat Med 12: 459-465. [PubMed]

8. Rasini V, Dominici M, Kluba T, Siegel G, Lusenti G, et al. (2013) Mesenchymal stromal/stem cells markers in the human bone marrow. Cytotherapy 15: 292 306. [PubMed]

9. Frenette PS, Pinho S, Lucas D, Scheiermann C (2013) Mesenchymal stem cell: keystone of the hematopoietic stem cell niche and a stepping-stone for regenerative medicine. Annu Rev Immunol 31: 285-316. [PubMed]

10. Bian ZY, Li G, Gan YK, Hao YQ, Xu WT, et al. (2009) Increased number of mesenchymal stem cell-like cells in peripheral blood of patients with bone sarcomas. Arch Med Res 40: 163-168. [PubMed]

11. Liu ZJ, Zhuge Y, Velazquez OC (2009) Trafficking and differentiation of mesenchymal stem cells. J Cell Biochem 106: 984-991. [PubMed]

12. Nedeau AE, Bauer RJ, Gallagher K, Chen H, Liu ZJ, et al. (2008) A CXCL5and bFGF-dependent effect of PDGF-B-activated fibroblasts in promoting trafficking and differentiation of bone marrow-derived mesenchymal stem cells. Exp Cell Res 314: 2176-2186. [PubMed]

13. Yu Q, Chen L, You Y, Zou C, Zhang Y, et al. (2011) Erythropoietin combined with granulocyte colony stimulating factor enhances MMP-2 expression in mesenchymal stem cells and promotes cell migration. Mol Med Report 4: 31 36. [PubMed]

14. Lee Y, Jung J, Cho KJ, Lee SK, Park JW, et al. (2013) Increased SCF/c-kit by hypoxia promotes autophagy of human placental chorionic plate-derived mesenchymal stem cells via regulating the phosphorylation of mTOR. J Cell Biochem 114: 79-88. [PubMed]

15. Berniakovich I, Giorgio M (2013) Low oxygen tension maintains multipotency, whereas normoxia increases differentiation of mouse bone marrow stromal cells. Int J Mol Sci 14: 2119-2134. [PubMed]

16. Williams AR, Hare JM (2011) Mesenchymal stem cells: biology, pathophysiology translational findings, and therapeutic implications for cardiac disease. Circ Res 109: 923-940. [PubMed]

17. Boland GM, Perkins G, Hall DJ, Tuan RS (2004) Wnt 3a promotes proliferation and suppresses osteogenic differentiation of adult human mesenchymal stem cells. J Cell Biochem 93: 1210-1230. [PubMed]

18. Mackay AM, Beck SC, Murphy JM, Barry FP, Chichester CO, et al. (1998) Chondrogenic differentiation of cultured human mesenchymal stem cells from marrow. Tissue Eng 4: 415-428. [PubMed]

19. Lamplot JD, Qin J, Nan G, Wang J, Liu X, et al. (2013) BMP9 signaling in stem cell differentiation and osteogenesis. Am J Stem Cells 2: 1-21. [PubMed]

20. Churchman SM, Ponchel F, Boxall SA, Cuthbert R, Kouroupis D, et al. (2012) Transcriptional profile of native CD271+ multipotential stromal cells: evidence for multiple fates, with prominent osteogenic and Wnt pathway signaling activity. Arthritis Rheum 64: 2632-2643. [PubMed]

21. Tomé $M$, López-Romero $P$, Albo $C$, Sepúlveda JC, Fernández-Gutiérrez $B$, et al. (2011) miR-335 orchestrates cell proliferation, migration and differentiation in human mesenchymal stem cells. Cell Death Differ 18: 985-995. [PubMed]

22. Buechli ME, Lamarre J, Koch TG (2013) MicroRNA-140 expression during chondrogenic differentiation of equine cord blood-derived mesenchymal stromal cells. Stem Cells Dev 22: 1288-1296. [PubMed]

23. Son YH, Ka S, Kim AY, Kim JB (2014) Regulation of Adipocyte Differentiation via MicroRNAs. Endocrinol Metab (Seoul) 29: 122-135. [PubMed]

24. Kim SY, Kim AY, Lee HW, Son YH, Lee GY, et al. (2010) miR-27a is a negative regulator of adipocyte differentiation via suppressing PPAR gamma expression. Biochem Biophys Res Commun 392: 323-328. [PubMed]

25. Wang Q, Li YC, Wang J, Kong J, Qi Y, et al. (2008) miR-17-92 cluster accelerates adipocyte differentiation by negatively regulating tumor-suppressor Rb2/p130. Proc Natl Acad Sci USA 105: 2889-2894. [PubMed]

26. Inose H, Ochi H, Kimura A, Fujita K, Xu R, et al. (2009) A microRNA regulatory mechanism of osteoblast differentiation. Proc Natl Acad Sci USA 106: 20794 20799. [PubMed]

27. Li Z, Hassan MQ, Volinia S, van Wijnen AJ, Stein JL, et al. (2008) A microRNA signature for a BMP2-induced osteoblast lineage commitment program. Proc Natl Acad Sci USA 105: 13906-13911. [PubMed]

28. Li H, Xie H, Liu W, Hu R, Huang B, et al. (2009) A novel microRNA targeting HDAC5 regulates osteoblast differentiation in mice and contributes to primary osteoporosis in humans. J Clin Invest 119: 3666-3677. [PubMed]

29. Takashima Y, Era T, Nakao K, Kondo S, Kasuga M, et al. (2007) Neuroepithelial cells supply an initial transient wave of MSC differentiation. Cell 129: 1377 1388. [PubMed]

30. Morikawa S, Mabuchi Y, Niibe K, Suzuki S, Nagoshi N, et al. (2009) Development of mesenchymal stem cells partially originate from the neural crest. Biochem Biophys Res Commun 379: 1114-1119. [PubMed]

31. Nagoshi N, Shibata S, Kubota Y, Nakamura M, Nagai Y, et al. (2008) Ontogeny and multipotency of neural crest-derived stem cells in mouse bone marrow, dorsal root ganglia, and whisker pad. Cell Stem Cell 2: 392-403. [PubMed]

32. Corselli M, Chen CW, Crisan M, Lazzari L, Péault B (2010) Perivascular ancestors of adult multipotent stem cells. Arterioscler Thromb Vasc Biol 30: 1104-1109. [PubMed]

33. Khan WS, Adesida AB, Tew SR, Lowe ET, Hardingham TE (2010) Bone marrow-derived mesenchymal stem cells express the pericyte marker $3 \mathrm{G} 5$ in culture and show enhanced chondrogenesis in hypoxic conditions. J Orthop Res 28: 834-840. [PubMed]

34. Feng J, Mantesso A, De Bari C, Nishiyama A, Sharpe PT (2011) Dual origin of mesenchymal stem cells contributing to organ growth and repair. Proc Nat Acad Sci USA 108: 6503-6508. [PubMed]

35. Battula VL, Evans KW, Hollier BG, Shi Y, Marini FC, et al. (2010) Epithelialmesenchymal transition-derived cells exhibit multilineage differentiation potential similar to mesenchymal stem cells. Stem Cells 28: 1435-1445. [PubMed]

36. Ehninger A, Trumpp A (2011) The bone marrow stem cell niche grows up: mesenchymal stem cells and macrophages move in. J Exp Med 208: 421-428. [PubMed]

37. Omatsu Y, Sugiyama T, Kohara H, Kondoh G, Fujii N, et al. (2010) The essential functions of adipo-osteogenic progenitors as the hematopoietic stem and progenitor cell niche. Immunity 33: 387-399. [PubMed]

38. Nagasawa T, Omatsu Y, Sugiyama T (2011) Control of hematopoietic stem cells by the bone marrow stromal niche: the role of reticular cells. Trends Immunol 32: 315-320. [PubMed]

39. Sugiyama T, Kohara H, Noda M, Nagasawa T (2006) Maintenance of the hematopoietic stem cell pool by CXCL12-CXCR4 chemokine signaling in bone marrow stromal cell niches. Immunity 25: 977-988. [PubMed]

40. Sugiyama T, Nagasawa T (2012) Bone marrow niches for hematopoietic stem cells and immune cells. Inflamm Allergy Drug Targets 11: 201-206. [PubMed]

41. Kohara H, Omatsu Y, Sugiyama T, Noda M, Fujii N, et al. (2007) Development of plasmacytoid dendritic cells in bone marrow stromal cell niches requires CXCL12-CXCR4 chemokine signaling. Blood 110: 4153-4160. [PubMed]

42. Noda M, Omatsu Y, Sugiyama T, Oishi S, Fujii N, et al. (2011) CXCL12-CXCR4 chemokine signaling is essential for NK-cell development in adult mice. Blood 117: 451-458. [PubMed]

43. Maijenburg MW, Kleijer M, Vermeul K, Mul EP, van Alphen FP, et al. (2012 The composition of the mesenchymal stromal cell compartment in human bone marrow changes during development and aging. Haematologica 97: 179-183. [PubMed]

44. Tormin A, Li O, Brune JC, Walsh S, Schütz B, et al. (2011) CD146 expression on primary nonhematopoietic bone marrow stem cells is correlated with in situ localization. Blood 117: 5067-5077. [PubMed]

45. Méndez-Ferrer S, Michurina TV, Ferraro F, Mazloom AR, Macarthur BD, et al. (2010) Mesenchymal and haematopoietic stem cells form a unique bone marrow niche. Nature 466: 829-834. [PubMed]

46. Méndez-Ferrer S, Lucas D, Battista M, Frenette PS (2008) Haematopoietic stem cell release is regulated by circadian oscillations. Nature 452: $442-447$. [PubMed]

47. Bedi B, Li JY, Tawfeek H, Baek KH, Adams J, et al. (2012) Silencing of parathyroid hormone (PTH) receptor 1 in T cells blunts the bone anabolic activity of PTH. Proc Natl Acad Sci USA 109: E725-733. [PubMed] 
Citation: EL Marsafy S, Larghero J, Bennaceur-Griscelli A, Turhan A (2014) Mesenchymal Stem Cells: Pivotal Players in Hematopoietic Stem Cell Microenvironment. J Stem Cell Res Ther 4: 225. doi:10.4172/2157-7633.1000225

48. Li JY, Adams J, Calvi LM, Lane TF, DiPaolo R, et al. (2012) PTH expands short-term murine hemopoietic stem cells through T cells. Blood 120: 43524362. [PubMed]

49. Legiran S, Brandi ML (2012) Bone mass regulation of leptin and postmenopausal osteoporosis with obesity. Clin Cases Miner Bone Metab 9: 145-149. [PubMed]

50. Ding L, Saunders TL, Enikolopov G, Morrison SJ (2012) Endothelial and perivascular cells maintain haematopoietic stem cells. Nature 481: 457-462. [PubMed]

51. Bethel M, Chitteti BR, Srour EF, Kacena MA (2013) The changing balance between osteoblastogenesis and adipogenesis in aging and its impact on hematopoiesis. Curr Osteoporos Rep 11: 99-106. [PubMed]

52. Guezguez B, Campbell CJ, Boyd AL, Karanu F, Casado FL, et al. (2013) Regional localization within the bone marrow influences the functional capacity of human HSCs. Cell Stem Cell 13: 175-189. [PubMed]

53. Kiel MJ, Yilmaz OH, Iwashita T, Yilmaz OH, Terhorst C, et al. (2005) SLAM family receptors distinguish hematopoietic stem and progenitor cells and reveal endothelial niches for stem cells. Cell 121: 1109-1121. [PubMed]

54. Zhang J, Niu C, Ye L, Huang $\mathrm{H}$, He X, et al. (2003) Identification of the haematopoietic stem cell niche and control of the niche size. Nature 425: 836841. [PubMed]

55. Arai F, Hirao A, Ohmura M, Sato H, Matsuoka S, et al. (2004) Tie2 angiopoietin-1 signaling regulates hematopoietic stem cell quiescence in the bone marrow niche. Cell 118: 149-161. [PubMed]

56. Lassailly F, Foster K, Lopez-Onieva L, Currie E, Bonnet D (2013) Multimoda imaging reveals structural and functional heterogeneity in different bone marrow compartments: functional implications on hematopoietic stem cells. Blood 122: 1730-1740. [PubMed]

57. Greenbaum A, Hsu YM, Day RB, Schuettpelz LG, Christopher MJ, et al. (2013) CXCL12 in early mesenchymal progenitors is required for haematopoietic stem-cell maintenance. Nature 495: 227-230. [PubMed]

58. Ding L, Morrison SJ (2013) Haematopoietic stem cells and early lymphoid progenitors occupy distinct bone marrow niches. Nature 495: 231-235. [PubMed]

59. Nagasawa T, Kikutani H, Kishimoto $T$ (1994) Molecular cloning and structure of a pre-B-cell growth-stimulating factor. Proc Natl Acad Sci USA 91: 2305-2309. [PubMed]

60. Punzel M, Zhang T, Liu D, Eckstein V, Ho AD (2002) Functional analysis of initial cell divisions defines the subsequent fate of individual human CD34+CD38- cells. Exp Hematol 30: 464-472. [PubMed]

61. Ho AD (2005) Kinetics and symmetry of divisions of hematopoietic stem cells. Exp Hematol 33: 1-8. [PubMed]

62. Huang S, Law P, Francis K, Palsson BO, Ho AD (1999) Symmetry of initial cell divisions among primitive hematopoietic progenitors is independet of ontogenic age and regulatory molecules. Blood 94: 2595-2604. [PubMed]

63. Freida D, Lecourt S, Cras A, Vanneaux V, Letort G, et al. (2013) Human bone marrow mesenchymal stem cells regulate biased DNA segregation in response to cell adhesion asymmetry. Cell Rep 5: 601-610. [PubMed]

64. Shin JW, Buxboim A, Spinler KR, Swift J, Christian DA, et al. (2014) Contractile forces sustain and polarize hematopoiesis from stem and progenitor cells. Cell Stem Cell 14: 81-93. [PubMed]

65. Blank U, Karlsson G, Karlsson S (2008) Signaling pathways governing stemcell fate. Blood 111: 492-503. [PubMed]

66. Luis TC, Naber BA, Roozen PP, Brugman MH, de Haas EF, et al. (2011) Canonical wnt signaling regulates hematopoiesis in a dosage-dependent fashion. Cell Stem Cell 9: 345-356. [PubMed]

67. Corrigan PM, Dobbin E, Freeburn RW, Wheadon H (2009) Patterns of Wnt/ Fzd/LRP gene expression during embryonic hematopoiesis. Stem Cells Dev 18: 759-772. [PubMed]

68. Reya T, Duncan AW, Ailles L, Domen J, Scherer DC, et al. (2003) A role for Wnt signalling in self-renewal of haematopoietic stem cells. Nature 423: 409414. [PubMed]

69. Jeannet G, Scheller M, Scarpellino L, Duboux S, Gardiol N, et al. (2008) Longterm, multilineage hematopoiesis occurs in the combined absence of betacatenin and gamma-catenin. Blood 111: 142-149. [PubMed]
70. Koch U, Wilson A, Cobas M, Kemler R, Macdonald HR, et al. (2008) Simultaneous loss of beta- and gamma-catenin does not perturb hematopoiesis or lymphopoiesis. Blood 111: 160-164. [PubMed]

71. Duncan AW, Rattis FM, DiMascio LN, Congdon KL, Pazianos G, et al. (2005) Integration of Notch and Wnt signaling in hematopoietic stem cell maintenance. Nat Immunol 6: 314-322. [PubMed]

72. Mureli S, Gans CP, Bare DJ, Geenen DL, Kumar NM, et al. (2013) Mesenchymal stem cells improve cardiac conduction by upregulation of connexin 43 through paracrine signaling. Am J Physiol Heart Circ Physiol 304: H600-609. [PubMed]

73. Ichii M, Frank MB, lozzo RV, Kincade PW (2012) The canonical Wnt pathway shapes niches supportive of hematopoietic stem/progenitor cells. Blood 119 : 1683-1692. [PubMed]

74. Nemeth MJ, Topol L, Anderson SM, Yang Y, Bodine DM (2007) Wnt5a inhibits canonical Wnt signaling in hematopoietic stem cells and enhances repopulation. Proc Natl Acad Sci USA 104: 15436-15441. [PubMed]

75. Murdoch B, Chadwick K, Martin M, Shojaei F, Shah KV, et al. (2003) Wnt$5 \mathrm{~A}$ augments repopulating capacity and primitive hematopoietic development of human blood stem cells in vivo. Proc Natl Acad Sci USA 100: 3422-3427. [PubMed]

76. Grumolato L, Liu G, Mong P, Mudbhary R, Biswas R, et al. (2010) Canonical and noncanonical Whts use a common mechanism to activate completely unrelated coreceptors. Genes Dev 24: 2517-2530. [PubMed]

77. Bigas A, Espinosa L (2012) Hematopoietic stem cells: to be or Notch to be Blood 119: 3226-3235. [PubMed]

78. Karanu FN, Murdoch B, Gallacher L, Wu DM, Koremoto M, et al. (2000) The notch ligand jagged-1 represents a novel growth factor of human hematopoietic stem cells. J Exp Med 192: 1365-1372. [PubMed]

79. Calvi LM, Adams GB, Weibrecht KW, Weber JM, Olson DP, et al. (2003) Osteoblastic cells regulate the haematopoietic stem cell niche. Nature 425 841-846. [PubMed]

80. Stier S, Cheng T, Dombkowski D, Carlesso N, Scadden DT (2002) Notch1 activation increases hematopoietic stem cell self-renewal in vivo and favors lymphoid over myeloid lineage outcome. Blood 99: 2369-2378. [PubMed]

81. Karanu FN, Yuefei L, Gallacher L, Sakano S, Bhatia M (2003) Differentia response of primitive human CD34- and CD34+ hematopoietic cells to the Notch ligand Jagged-1. Leukemia 17: 1366-1374. [PubMed]

82. Arai F, Suda $T$ (2007) Maintenance of quiescent hematopoietic stem cells in the osteoblastic niche. Ann N Y Acad Sci 1106: 41-53. [PubMed]

83. Yamazaki S, Ema H, Karlsson G, Yamaguchi T, Miyoshi H, et al. (2011) Nonmyelinating schwann cells maintain hematopoietic stem cell hibernation in the bone marrow niche. Cell 147: 1146-1158. [PubMed]

84. Eliasson P, Rehn M, Hammar P, Larsson P, Sirenko O, et al. (2010) Hypoxia mediates low cell-cycle activity and increases the proportion of long-termreconstituting hematopoietic stem cells during in vitro culture. Exp Hematol 38 : 301-310. [PubMed]

85. Nwajei F, Konopleva M (2013) The bone marrow microenvironment as niche retreats for hematopoietic and leukemic stem cells. Adv Hematol 2013: 953982 [PubMed]

86. Wang Y, Liu Y, Malek SN, Zheng P, Liu Y (2011) Targeting HIF1a Eliminates Cancer Stem Cells in Hematological Malignancies. Cell Stem Cell 8: 399-411. [PubMed]

87. Zhang H, Li H, Xi HS, Li S (2012) HIF1 $\alpha$ is required for survival maintenance of chronic myeloid leukemia stem cells. Blood 119: 2595-2607. [PubMed]

88. Lévesque JP, Helwani FM, Winkler IG (2010) The endosteal 'osteoblastic' niche and its role in hematopoietic stem cell homing and mobilization. Leukemia 24 1979-1992. [PubMed]

89. London NR, Li DY (2011) Robo4-dependent Slit signaling stabilizes the vasculature during pathologic angiogenesis and cytokine storm. Curr Opin Hematol 18: 186-190. [PubMed]

90. Winkler IG, Pettit AR, Raggatt LJ, Jacobsen R, Forristal CE, et al. (2012) Hematopoietic stem cell (HSC) mobilizing agents G-CSF, cyclophosphamide or AMD3100 have distinct mechanisms of action on bone marrow HSC niches and bone formation. Leukemia 26: 1594-1601. [PubMed]

91. Chow A, Lucas D, Hidalgo A, Méndez-Ferrer S, Hashimoto D, et al. (2011) 
Citation: EL Marsafy S, Larghero J, Bennaceur-Griscelli A, Turhan A (2014) Mesenchymal Stem Cells: Pivotal Players in Hematopoietic Stem Cell Microenvironment. J Stem Cell Res Ther 4: 225. doi:10.4172/2157-7633.1000225

Page 8 of 9

Bone marrow CD169+ macrophages promote the retention of hematopoietic stem and progenitor cells in the mesenchymal stem cell niche. J Exp Med 208: 261-271. [PubMed]

92. Favier B, Lemaoult J, Lesport E, Carosella ED (2010) ILT2/HLA-G interaction impairs NK-cell functions through the inhibition of the late but not the early events of the NK-cell activating synapse. FASEB J 24: 689-699. [PubMed]

93. Ren G, Roberts Al, Shi Y (2011) Adhesion molecules: key players in Mesenchymal stem cell-mediated immunosuppression. Cell Adh Migr 5: 20-22. [PubMed]

94. Zinöcker S, Vaage JT (2012) Rat mesenchymal stromal cells inhibit T cell proliferation but not cytokine production through inducible nitric oxide synthase. Front Immunol 3: 62. [PubMed]

95. Meisel R, Zibert A, Laryea M, Göbel U, Däubener W, et al. (2004) Human bone marrow stromal cells inhibit allogeneic T-cell responses by indoleamine 2,3-dioxygenase-mediated tryptophan degradation. Blood 103: 4619-4621. [PubMed]

96. Ninomiya M, Abe A, Katsumi A, Xu J, Ito M, et al. (2007) Homing, proliferation and survival sites of human leukemia cells in vivo in immunodeficient mice. Leukemia 21: 136-142. [PubMed]

97. Krause DS, Fulzele K, Catic A, Sun CC, Dombkowski D, et al. (2013) Differentia regulation of myeloid leukemias by the bone marrow microenvironment. Nat Med 19: 1513-1517. [PubMed]

98. Raaijmakers MH, Mukherjee S, Guo S, Zhang S, Kobayashi T, et al. (2010) Bone progenitor dysfunction induces myelodysplasia and secondary leukaemia. Nature 464: 852-857. [PubMed]

99. Geyh S, Oz S, Cadeddu RP, Fröbel J, Brückner B, et al. (2013) Insufficien stromal support in MDS results from molecular and functional deficits of mesenchymal stromal cells. Leukemia 27: 1841-1851. [PubMed]

100. Flores-Figueroa E, Montesinos JJ, Flores-Guzmán P, Gutiérrez-Espíndola G, Arana-Trejo RM, et al. (2008) Functional analysis of myelodysplastic syndromes-derived mesenchymal stem cells. Leuk Res 32: 1407-1416. [PubMed]

101. de Vasconcellos JF, Laranjeira AB, Zanchin NI, Otubo R, Vaz TH, et al. (2011) Increased CCL2 and IL-8 in the bone marrow microenvironment in acute lymphoblastic leukemia. Pediatr Blood Cancer 56: 568-577. [PubMed]

102. Quéré R, Andradottir S, Brun AC, Zubarev RA, Karlsson G, et al. (2011) High levels of the adhesion molecule CD44 on leukemic cells generate acute myeloid leukemia relapse after withdrawal of the initial transforming event. Leukemia 25: 515-526. [PubMed]

103. Pusic I, DiPersio JF (2010) Update on clinical experience with AMD3100, an SDF-1/CXCL12-CXCR4 inhibitor, in mobilization of hematopoietic stem and progenitor cells. Curr Opin Hematol 17: 319-326. [PubMed]

104. Parameswaran R, Yu M, Lim M, Groffen J, Heisterkamp N (2011) Combination of drug therapy in acute lymphoblastic leukemia with a CXCR4 antagonist. Leukemia 25: 1314-1323. [PubMed]

105. Schmidt T, Carmeliet $P$ (2011) Angiogenesis: a target in solid tumors, also in leukemia? Hematology Am Soc Hematol Educ Program 2011: 1-8. [PubMed]

106.Zhang B, Ho YW, Huang Q, Maeda T, Lin A, et al. (2012) Altered microenvironmental regulation of leukemic and normal stem cells in chronic myelogenous leukemia. Cancer Cell 21: 577-592. [PubMed]

107. Iwamoto S, Mihara K, Downing JR, Pui CH, Campana D (2007) Mesenchymal cells regulate the response of acute lymphoblastic leukemia cells to asparaginase. J Clin Invest 117: 1049-1057. [PubMed]

108. Hao M, Zhang L, An G, Meng H, Han Y, et al. (2011) Bone marrow stromal cells protect myeloma cells from bortezomib induced apoptosis by suppressing microRNA-15a expression. Leuk Lymphoma 52: 1787-1794. [PubMed]

109. Arnulf B, Lecourt S, Soulier J, Ternaux B, Lacassagne MN, et al. (2007) Phenotypic and functional characterization of bone marrow mesenchymal stem cells derived from patients with multiple myeloma. Leukemia 21: 158163. [PubMed]

110. Li B, Fu J, Chen P, Zhuang W (2010) Impairment in immunomodulatory function of mesenchymal stem cells from multiple myeloma patients. Arch Med Res 41: 623-633. [PubMed]

111. Quante M, Tu SP, Tomita H, Gonda T, Wang SS, et al. (2011) Bone marrow- derived myofibroblasts contribute to the mesenchymal stem cell niche and promote tumor growth. Cancer Cell 19: 257-272. [PubMed]

112. Amé-Thomas $P$, Maby-El Hajjami H, Monvoisin C, Jean R, Monnier D, et al. (2007) Human mesenchymal stem cells isolated from bone marrow and lymphoid organs support tumor B-cell growth: role of stromal cells in follicular lymphoma pathogenesis. Blood 109: 693-702. [PubMed]

113. Al Saleh S, Sharaf LH, Luqmani YA (2011) Signalling pathways involved in endocrine resistance in breast cancer and associations with epithelial to mesenchymal transition Int J Oncol 38: 1197-1217. [PubMed]

114. Gao H, Priebe W, Glod J, Banerjee D (2009) Activation of signal transducers and activators of transcription 3 and focal adhesion kinase by stromal cellderived factor 1 is required for migration of human mesenchymal stem cells in response to tumor cell-conditioned medium. Stem Cells 27: 857-865. [PubMed]

115. Suzuki K, Sun R, Origuchi M, Kanehira M, Takahata T, et al. (2011) Mesenchymal Stromal Cells Promote Tumor Growth Through the Enhancement of Neovascularization. Mol Med 17: 579-587. [PubMed]

116. Liu WH, Liu JJ, Wu J, Zhang LL, Liu F, et al. (2013) Novel mechanism of inhibition of dendritic cells maturation by mesenchymal stem cells via interleukin-10 and the JAK1/STAT3 signaling pathway. PLoS One 8: e55487. [PubMed]

117. Kéramidas $M$, de Fraipont $F$, Karageorgis A, Moisan A, Persoons $V$, et al (2013) The dual effect of MSC on tumour growth and tumour angiogenesis. Stem Cell Res Ther 4: 41. [PubMed]

118. Saki N, Abroun S, Farshdousti Hagh M, Asgharei F (2011) Neoplastic bone marrow niche: hematopoietic and mesenchymal stem cells. Cell J 13: 131136. [PubMed]

119. Halpern JL, Kilbarger A, Lynch CC (2011) Mesenchymal stem cells promote mammary cancer cell migration in vitro via the CXCR2 receptor. Cancer Lett 308: 91-99. [PubMed]

120.Zhu Y, Sun Z, Han Q, Liao L, Wang J, et al. (2009) Human mesenchymal stem cells inhibit cancer cell proliferation by secreting DKK-1. Leukemia 23: 925-933. [PubMed]

121. Qiao L, Xu ZL, Zhao TJ, Ye LH, Zhang XD (2008) Dkk-1 secreted by mesenchymal stem cells inhibits growth of breast cancer cells via depression of Wnt signalling. Cancer Lett 269: 67-77. [PubMed]

122. Wang J, Bian C, Liao L, Zhu Y, Li J, et al. (2009) Inhibition of hepatic stellate cells proliferation by mesenchymal stem cells and the possible mechanisms. Hepatol Res 29: 1219-1228. [PubMed]

123. Bueno C, Montes R, Catalina P, Rodríguez R, Menendez P (2011) Insights into the cellular origin and etiology of the infant pro-B acute lymphoblastic leukemia with MLL-AF4 rearrangement. Leukemia 25: 400-410. [PubMed]

124. Menendez P, Catalina P, Rodríguez R, Melen GJ, Bueno C, et al. (2009) Bone marrow mesenchymal stem cells from infants with MLL-AF4+ acute leukemia harbor and express the MLL-AF4 fusion gene. J Exp Med 206: 3131-3141. [PubMed]

125. Pieri L, Guglielmelli P, Bogani C, Bosi A, Vannucchi AM, et al. (2008) Mesenchymal stem cells from JAK2(V617F) mutant patients with primary myelofibrosis do not harbor JAK2 mutant allele. Leuk Res 32: 516-517. [PubMed]

126. Wöhrer S, Rabitsch W, Shehata M, Kondo R, Esterbauer H, et al. (2007) Mesenchymal stem cells in patients with chronic myelogenous leukaemia or bi-phenotypic $\mathrm{Ph}+$ acute leukaemia are not related to the leukaemic clone. Anticancer Res 27: 3837-3841.

127. Soenen-Cornu V, Tourino C, Bonnet ML, Guillier M, Flamant S, et al. (2005) Mesenchymal cells generated from patients with myelodysplastic syndromes are devoid of chromosomal clonal markers and support short- and long-term hematopoiesis in vitro. Oncogene 24: 2441-2448.

128. Rodríguez R, García-Castro J, Trigueros C, García Arranz M, Menéndez P (2012) Multipotent mesenchymal stromal cells: clinical applications and cancer modeling. Adv Exp Med Biol 741: 187-205. [PubMed]

129. Mantri S, Mohapatra PC (2014) In-vitro Behavior of Human Umbilical Cord Blood Stem Cells Towards Serum Based Minimal Cytokine Growth Conditions. Indian J Clin Biochem 29: 279-289. [PubMed]

130. Kalpakci KN, Brown WE, Hu JC, Athanasiou KA (2014) Cartilage tissue 
Citation: EL Marsafy S, Larghero J, Bennaceur-Griscelli A, Turhan A (2014) Mesenchymal Stem Cells: Pivotal Players in Hematopoietic Stem Cell Microenvironment. J Stem Cell Res Ther 4: 225. doi:10.4172/2157-7633.1000225

Page 9 of 9

engineering using dermis isolated adult stem cells: the use of hypoxia during expansion versus chondrogenic differentiation. PLoS One 9: e98570. [PubMed]

131. Al-Saqi SH, Saliem M, Asikainen S, Quezada HC, Ekblad A, et al. (2014) Defined serum-free media for in vitro expansion of adipose-derived mesenchymal stem cells. Cytotherapy 16: 915-926. [PubMed]

132. Pham PV, Vu NB, Pham VM, Truong NH, Pham TL, et al. (2014) Good manufacturing practice-compliant isolation and culture of human umbilical cord blood-derived mesenchymal stem cells. J Transl Med 12: 56. [PubMed]

133. Iudicone P, Fioravanti D, Bonanno G, Miceli M, Lavorino C, et al. (2014) Pathogen-free, plasma-poor platelet lysate and expansion of human mesenchymal stem cells. J Transl Med 12: 28. [PubMed]

134. Law S, Chaudhuri S (2013) Mesenchymal stem cell and regenerative medicine: regeneration versus immunomodulatory challenges. Am J Stem Cells 2: 22-38. [PubMed]

135. Motaln H, Schichor C, Lah TT (2010) Human mesenchymal stem cells and their use in cell-based therapies. Cancer 116: 2519-2530. [PubMed]

136. Lalu MM, Mclntyre L, Pugliese C, Fergusson D, Winston BW, et al. (2012) Safety of cell therapy with mesenchymal stromal cells (SafeCell): a systematic review and meta-analysis of clinical trials. Canadian Critical Care Trials Group. PLoS One 7: e47559. [PubMed]

137. Fan X, Gay FP, Ong SY, Ang JM, Chu PP, et al. (2013) Mesenchymal stroma cell supported umbilical cord blood ex vivo expansion enhances regulatory $\mathrm{T}$ cells and reduces graft versus host disease. Cytotherapy 15: 610-619. [PubMed]

138. Schuettpelz LG, Link DC (2011) Niche competition and cancer metastasis to bone. J Clin Invest 121: 1253-1255. [PubMed]
139. Kuçi S, Kuçi Z, Kreyenberg H, Deak E, Pütsch K, et al. (2010) CD271 antigen defines a subset of multipotent stromal cells with immunosuppressive and lymphohematopoietic engraftment-promoting properties. Haematologica 95 651-659. [PubMed]

140. Ahn JY, Park G, Shim JS, Lee JW, Oh IH (2010) Intra marrow injection of beta-catenin-activated, but not naive mesenchymal stromal cells stimulates self-renewal of hematopoietic stem cells in bone marrow. Exp Mol Med 42 122-131. [PubMed]

141. Dwyer RM, Potter-Beirne SM, Harrington KA, Lowery AJ, Hennessy E, et al. (2007) Monocyte chemotactic protein-1 secreted by primary breast tumors stimulates migration of mesenchymal stem cells. Clin Cancer Res 13: 50205027. [PubMed]

142. Birnbaum T, Roider J Schankin CJ, Padovan CS, Schichor C et al. (2007) Malignant gliomas actively recruit bone marrow stromal cells by secreting angiogenic cytokines. J Neurooncol 83: 241-247. [PubMed]

143. Bak XY, Dang HL, Yang J, Ye K, Lee EX, et al. (2011) Human Embryonic Stem Cell-derived Mesenchymal Stem Cells as Cellular Delivery Vehicles for Prodrug Gene Therapy of Glioblastoma. Hum Gene Ther 22: 1365-1377. [PubMed]

144. Xin H, Sun R, Kanehira M, Takahata T, Itoh J, et al. (2009) Intratracheal delivery of CX3CL1-expressing mesenchymal stem cells to multiple lung tumors. Mol Med 15: 321-327. [PubMed]

145.Luetzkendorf J, Mueller LP, Mueller T, Caysa H, Nerger K, et al. (2010) Growth inhibition of colorectal carcinoma by lentiviral TRAIL-transgenic human mesenchymal stem cells requires their substantial intratumoral presence. $J$ Cell Mol Med 14: 2292-2304. [PubMed]

146. Micheau O, Shirley S, Dufour F (2013) Death receptors as targets in cancer Br J Pharmacol 169: 1723-1744. [PubMed] 